\title{
$\overline{A M} \mid$ SCHOOL OF LAW

Volume 6

Number 2 Unsolicited Issue

Article 3

$5-1-2020$

\section{Drone Delivery and the Takings Clause}

Brian M. Miller

University of Virginia School of Law, bmm5pc@virginia.edu

Follow this and additional works at: https://scholarship.law.tamu.edu/journal-of-property-law

Part of the Property Law and Real Estate Commons

\section{Recommended Citation}

Brian M. Miller, Drone Delivery and the Takings Clause, 6 Tex. A\&M J. Prop. L. 139 (2020).

This Student Article is brought to you for free and open access by Texas A\&M Law Scholarship. It has been accepted for inclusion in Texas A\&M Journal of Property Law by an authorized editor of Texas A\&M Law Scholarship. For more information, please contact aretteen@law.tamu.edu. 


\title{
Drone Delivery and the Takings Clause
}

\author{
By: Brian M. Miller †
}

Amazon, Inc.'s fledgling drone shipping service, "Prime Air," and similar services, may pose a new threat to private property rights. Companies that ship by drone would likely have to fly the drones over private land. But who owns the low-altitude airspace above private land? That issue is unsettled, but the common law supports the view that low-altitude airspace belongs to the landowners beneath. If that is correct, companies like Amazon have two main options to get drone shipping off the ground: (1) pay the landowners on the intended routes for an easement through their low-altitude airspace, or (2) count on the government to compel easements through these spaces.

The second option presents a Takings Clause problem. Because forced easements of flight intrude on landowner rights, landowners burdened by drone easements could potentially prove a per se taking. But even if drone easements are not per se takings, case law and the "character of the government action" factor in the Penn Central analysis give landowners a fighting chance to prove a regulatory taking.

Overall, the Takings Clause could be a valuable tool for both economic efficiency and equity, requiring beneficiaries of drone easements to compensate those burdened by the easements. If drone shipping takes off in the U.S., current law may ensure that the negative externalities will not fall solely on the surface landowners.

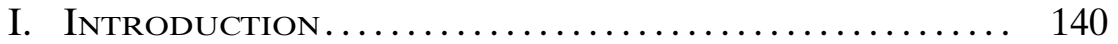

II. The Owner's Right to Exclude from Low-

Altitude Airspace ........................... 142

A. The Present Bounds of Navigable Airspace ........ 143

B. Exclusionary Trespass-Like Protections ........... 145

III. The Navigability Exception to Exclusionary

Rights ................................... 146

IV. Forced Drone Easements as Governmental

TAKINGS ................................. 150

A. Forced Drone Easements as Permanent Physical Occupations................................ 150

B. Forced Drone Easements as Penn Central Takings.. 154

1. The Character of the Government Action and its Unique Importance ................... 155

a. The Precedential Weight of the Character Factor............................. 155

b. The Policy Significance of the Character Factor................................. 157

2. The Extent of Diminution in Value .......... 162

3. Interference with Reasonable InvestmentBacked Expectations.................... 163

DOI: https://doi.org/10.37419/JPL.V6.I2.3

$\dagger$ J.D., University of Virginia School of Law; B.A. North Carolina State University. Special thanks to Professor Maureen E. Brady for her invaluable advice throughout the research and drafting process. Thanks as well to the editors of the Texas A\&M Journal of Property Law for the thoughtful suggestions and edits. 
V. Takings Theory Applied to Forced Drone

EASEMEnTs ....................................

VI. Conclusion .................................... 167

\section{INTRODUCTION}

The unmanned aircraft showcases this century's technological flourishing across sectors. "Drones" reshaped military reconnaissance and offensive maneuvers by providing an accurate and safer alternative to manned planes. They are evolving law enforcement by enabling bird's-eye views at lower cost and better visibility than helicopters. Commerce is the next frontier.

Companies may look to drones for a cutting-edge and cost-effective way to build a loyal customer base. Amazon has announced "Prime Air," hoping to enable online customers to click "order" and see their product land at their front door in a matter of minutes. ${ }^{1}$ It is not yet active in the United States to any significant scale, but if all goes Amazon's way, it will be soon. The company released preliminary plans for its "Hives," business and shipping centers providing for easy entry and exit of drones. ${ }^{2}$

Shipping drones do not yet swarm from Amazon Hives in the United States, perhaps in part because of property law concerns. To ship by drone, Amazon would have to traverse wide swaths of lowaltitude airspace. Shipping trucks and vans can travel on public highways. Shipping planes can fly at high altitudes within FAA jurisdiction, but most drones would travel within 500 feet of the ground. As of now, it is unclear who owns this airspace. ${ }^{3}$

The answer to this question might determine whether drone shipping gains traction in the United States at all, and it certainly will influence which companies will offer the service. If the federal government owns low-altitude airspace and can regulate its usage through the FAA, Amazon would only need permission from the FAA to fly drones in certain altitude zones. Amazon has already released a proposal for "drone zoning," which divides the air space by altitude levels and regulates usage in those spaces by type of drone. ${ }^{4}$

1. Dennis Green, Amazon Unveils a New Prime Air Drone it Says 'Within Months' Will Start Delivering Packages, Bus. Insider (June 5, 2019, 1:36 PM), https:// www.businessinsider.com/amazon-unveils-new-drone-prime-air-2019-6.

2. Kaya Yurieff, Amazon Patent Reveals Drone Delivery 'Beehives', CNN (June 23, 2017, 9:44 AM 2017), http://money.cnn.com/2017/06/23/technology/amazon-dronebeehives/index.html.

3. This article does not focus on the option of flying drones only in airspace directly above public roads. In such instances the companies may avoid the takings issue altogether (though presumably such a practice would increase the distance and time required for most drone deliveries compared to the alternative explored in this article, reducing the efficiency of the process).

4. Revising the Airspace Model for the Safe Integration of Small Unmanned Aircraft Systems, Amazon Prime AIR (July 2015), https://images-na.ssl-images-ama- 
But if surface landowners own the low-altitude airspace, Amazon and other entities would have to jump through more hoops. Companies would have two main options moving forward: (1) they could obtain easements of passage through all airspace in which they want to fly (this would likely require contracting with every individual surface land owner beneath the desired flight paths); or (2) the local, state, or federal government could require private landowners to keep the space open to others for certain uses. ${ }^{5}$ From the shippers' perspective, the major drawbacks of the first option are cost and individual holdouts. The major drawback of the second option is that the Takings Clause of the Fifth Amendment may require the government to justly compensate every landowner for the property taken.

So far, the bulk of the literature on private drone usage as it relates to property law comes from Professor Troy Rule. Professor Rule scoured the common law and concluded that state and local governments, if not Congress, should pass more specific protections for surface landowners that affirmatively establish exclusionary rights to airspace up to 500 feet above the ground. ${ }^{6}$ He has noted in passing that if the FAA instead asserted jurisdiction over such airspace and allowed private entities to regularly fly drones through the airspace, it would "arguably orchestrate one of the largest uncompensated transfers of property interests in United States history." 7 Because the exact mechanisms for evaluating drone easements as a matter of the takings doctrine are unclear, this Article seeks to answer that issue.

This Article will argue that the common law of navigable airspace and the Supreme Court's takings jurisprudence provide landowners with a solid constitutional claim should governments authorize the low-altitude flights of commercial shipping drones over their land. Although the case law merely whispers to airspace rights below 500 feet, a couple things are clear: the FAA has not substantially asserted jurisdiction there, ${ }^{8}$ and no outside party has the right to fly within the immediate reaches of the land. These, along with common law exclusionary rights against other sorts of low-altitude intrusions, show

zon.com/images/G/01/112715/download/Amazon_Revising_the_Airspace_Model_for_ the_Safe_Integration_of_sUAS.pdf.

5. Because no government has forced any such "drone easement" so far, it is not clear whether such future measures would only prohibit landowners from excluding drones from their low-altitude airspace, or go further and require them to keep open certain specific corridors in which no development or any other obstructing activity would be permitted. The nature and severity of such forced easements will affect whether such actions are takings requiring just compensation. (2015)

6. Troy A. Rule, Airspace in an Age of Drones, 95 B.U.L. Rev. 155, 158-59, 208

7. Troy A. Rule, Drone Zoning, 95 N.C.L. Rev. 133, 171 (2016).

8. There are limited exceptions, like the District of Columbia area. See DC No Drone Zone, Fed. Aviation Admin., https://www.faa.gov/uas/resources/community engagement/no_drone_zone/dc/ (last modified Aug. 7, 2019, 1:35 PM). 
that if anyone owns this airspace, it is the landowner. Next, Causby, ${ }^{9}$ Loretto ${ }^{10}$ and Penn Central ${ }^{11}$ give courts a foundation to rule that forced permanent easements of flight are takings requiring just compensation. Finally, courts should so rule, because to do otherwise would frustrate the expectations of property owners for the sake of propping up an emerging industry of uncertain public utility.

Business owners and landowners alike make investments by relying on how they expect to use their resources. ${ }^{12}$ Companies like Amazon may hesitate to invest in drone shipping if they will either have to pay for individual easements or gamble on the outcome of eminent domain proceedings, which are costly to the government. Prospective landowners may be less willing to pay top dollar for land if they know the airspace immediately above that land will be buzzing with drones. And current landowners may be limited in developing their land vertically if they expect to have to leave that airspace open for drone flights. In other words, the state of the law on these issues, whether clear or up in the air, will impact both small-scale residential and large-scale commercial land development.

Part II of this Article focuses on defining the ownership of lowaltitude airspace based on the common law. It concludes that surface landowners own the low-altitude airspace above their land by default. Part III explains why the doctrine of navigability, which applies to water, should not apply to low-altitude airspace to force landowners to open their airspace for travel. Part IV explores why a taking occurs when government action forces landowners to open an easement of travel through their private airspace. And Part V observes how classifying forced drone easements as takings comports with major economic theories of takings law.

\section{The Owner's Right to ExClude From Low-Altitude Airspace}

Minimal precedent speaks directly to property rights in low-altitude airspace. Even so, two things are clear: (1) Airspace above 500 feet is navigable and controllable by the FAA; ${ }^{13}$ (2) surface landowners do own some portion of the low-altitude airspace, even if this portion has not yet been clearly defined. ${ }^{14}$ So, a battle rages over who properly

9. United States v. Causby, 328 U.S. 256 (1946).

10. Loretto v. Teleprompter Manhattan CATV Corp., 458 U.S. 419 (1982).

11. Penn Cent. Transp. Co. v. City of New York, 438 U.S. 104 (1978).

12. See, e.g., Juliet Kostritsky, Uncertainty, Reliance, Preliminary Negotiations and the Holdup Problem, 61 SMU L. Rev. 1377, 1378 (Fall 2008) (pointing out that many factors that contribute to uncertainty may affect contract parties' incentives to reach agreements).

13. 14 C.F.R. § 91.119(b)-(c) (2018).

14. See, e.g., United States v. Causby, 328 U.S. 256, 264 (1946) (considering it "obvious that if the landowner is to have full enjoyment of the land, he must have exclusive control of the immediate reaches of the enveloping atmosphere"). 
owns the space between the ground and 500 feet. Court precedent has left the legal field to quarrel about how low or frequent invasions of that airspace must be to trigger protections for landowners. This section ultimately agrees with Professor Rule that the common law tilts in favor of the underlying surface landowners owning this airspace. ${ }^{15}$

\section{A. The Present Bounds of Navigable Airspace}

The federal government has jurisdiction over navigable airspace. Congress has defined "navigable airspace" to be "at or above safe altitudes of flight." 16 In most of the United States, the FAA regulates this space, which it usually considers as the space at or above 500 feet. ${ }^{17}$

The federal government may freely regulate this space because of an apparent carve-out of private airspace rights by the Supreme Court in Causby. ${ }^{18}$ Before that case there was no clear statement on property rights in low-altitude airspace, at least regarding unwanted flights. The ad coelum doctrine was the common law default-landowners owned the skies above and the depths beneath their surface land. ${ }^{19}$ The Causby Court took the expansiveness of that rule and put a roof over it-but where exactly did it place the roof?

Mr. Causby operated a farm and lived right next to an airport the United States military frequently used. ${ }^{20}$ Planes often flew over his land at altitudes under 100 feet. $^{21}$ The noise from the planes distressed Mr. Causby's chickens, causing them to fly into the walls of their coop and die. ${ }^{22}$ Mr. Causby sued, arguing the government flights were a taking of his private property in violation of the Fifth Amendment. ${ }^{23}$

The Supreme Court agreed, and it made some new rules along the way. First, it cast aside the ad coelum doctrine in its absolute form as "ha[ving] no place in the modern world." ${ }^{4}$ Next, though it recognized the need for a public highway through some portion of the air for plane travel, it also announced a victory for private landowners by affirming that they must have "exclusive control of the immediate reaches of the enveloping atmosphere." 25 The only other step the

15. See generally Rule, supra note 6 .

16. 49 U.S.C. \$ 40102(a)(32) (2012).

17. 14 C.F.R. \& 91.119(b)-(c).

18. Causby, 328 U.S. at 264.

19. See, e.g., Keith B. Hall, Hydraulic Fracturing: If Fractures Cross Property Lines, is There an Actionable Subsurface Trespass?, 54 NAt. Resources J. 361, 376 (Fall 2014).

20. Causby, 328 U.S. at 258-59.

21. Id. at 258 .

22. Id. at 259 .

23. Id. at 258 .

24. Id. at 261.

25. Id. at 264. 
Court took to define "immediate reaches" was to say that a taking occurs when flights are of such frequency and proximity as to constitute "a direct and immediate interference with the enjoyment and use of the land." 26

It is important to note that this case was a takings action instead of a nuisance action. Successful nuisance actions must only show unreasonable interference with the use and enjoyment of land. Alternatively, successful takings actions must show a confiscation of something owned by a private party in service of the public. ${ }^{27}$ The Court could have said that Mr. Causby stated a claim for nuisance, but it did not. It found a taking, meaning the government used something Mr. Causby owned. Other things being equal, the "direct and immediate interference" standard looks like a nuisance balancing test. But the Court clarified that landowners must have dominion over the immediate reaches of the atmosphere. So, the fact the flights constituted a taking confirms Mr. Causby had a property right to that airspace.

Causby thus gestures to exclusionary rights for airspace under 100 feet; but what about airspace higher than that, and what about something smaller and quieter than a military plane?

Although the Supreme Court has not addressed such questions directly, it has looked at the issue of government surveillance by helicopter in low-altitude airspace. In Florida v. Riley, the Court held that surveillance from a helicopter flying over a residential property at 400 feet was not a "search," so it did not require a warrant under the Fourth Amendment. ${ }^{28}$ It said helicopters are not bound by the lower limits of navigable airspace that constrain other aircrafts and that "[a]ny member of the public could legally have been flying over [the] property in a helicopter" at that height and observed the things the government observed. ${ }^{29}$

Landowners may see cause for concern from cases like this one. If the floor of navigable airspace for helicopters is lower than 500 feet, presumably that is because helicopters can fly at that altitude more safely than planes can. ${ }^{30}$ If public airspace is defined by the aircraft's ability to safely fly there, then the navigable airspace floor will continue plunging downward as aircrafts like drones become more adept at low-altitude navigation.

26. Id. at 266.

27. U.S. Const. amend. V. (The Takings Clause requires just compensation whenever private property is taken by the government for public use. Explicitly built into this provision is the prerequisite that "private property" that is taken.).

28. Florida v. Riley, 488 U.S. 445, 452 (1989).

29. Id. at 451.

30. See 49 U.S.C. $\$ 40102(a)(32)$ (2012) (defining "navigable airspace" as airspace at or above safe altitudes of flight) (emphasis added). 
There may be less cause for concern than first appears. Cases involving a search, such as Riley, are bound by expectations of privacy. ${ }^{31}$ The fact that members of the public could fly a helicopter at 400 feet meant the defendant did not have a reasonable expectation of privacy against the same activity by the police. Next, the fact that members of the public could legally fly a helicopter at 400 feet does not mean property owners forced to allow such activities over their houses have no cause of action. Finally, in Riley, the Court thought people could fly helicopters at 400 feet because the FAA lacks jurisdiction there. ${ }^{32}$ So, though Riley addressed the issue of government surveillance in low-altitude airspace, it did not address exclusionary rights enforceable in private suits.

\section{B. Exclusionary Trespass-Like Protections}

Low-altitude airspace rights are not generally governed by vague nuisance-like balancing tests. Instead, as Professor Rule has noted, "[m]ost areas of property law treat low-altitude airspace as equivalent to surface land, using exclusion-based rules to strongly protect landowners' interests in that space." 33 Because these exclusionary rights do not depend on the form of encroachment or the severity of resulting harm, the right truly is a property interest ${ }^{34}$ that could be enforced against something like drone flights as well.

Surface level trespass laws give landowners the right to exclude others from entering their land. This can come in the form of an injunction against further invasion of the property or damages for past trespasses. ${ }^{35}$ Importantly, damages are generally available even if the trespass caused no real harm to the land. ${ }^{36}$ Courts consider the "right to exclude" as such a vital stick in the bundle of property rights that they presume harm whenever a party infringes on that right. ${ }^{37}$

Courts have recognized a similar right to exclude from low-altitude airspace in some contexts. For example, property owners generally have the right to exclude neighbors from encroaching across the property line with tree branches, buildings, or other structures. ${ }^{38}$ Similar to trespass to surface land, the landowner's right to exclude does not

31. See, e.g., Riley, 488 U.S. at 452 (O'Connor, J., concurring) (noting that "police observation of the greenhouse in Riley's curtilage from a helicopter passing at an altitude of 400 feet did not violate an expectation of privacy.").

32. Riley, 488 U.S. at 451 ("[the Court] would have a different case if flying at that altitude had been contrary to law or regulation.").

33. Rule, supra note 6, at 182.

34. Instead of a "liability" interest.

35. See, e.g., Jacque v. Steenberg Homes, 563 N.W.2d 154, 163-64 (Wis. 1997) (affirming a $\$ 100,000$ punitive damage award for a trespass in addition to mere injunction).

36. See, e.g., id. (affirming a damage award for a trespass even when there was no harm done to the plaintiff's property).

37. Id. at 159.

38. Rule, supra note 6 , at 182-83. 
depend on a showing of harm or that the encroachment interferes with the landowner's use and enjoyment of her property. ${ }^{39}$

The same rights could apply to airspace encroachments via flights. Post-Causby, governments typically pay private parties near airports for easements to travel through the low-altitude airspace or gain prescriptive easements through frequent extended use. ${ }^{40}$ An easement assumes the traversed area belongs to someone else. ${ }^{41}$ So, the assumption post-Causby that governments need easements to fly in the low-altitude airspace over private land shows that contracting parties think this space belongs to the landowners.

Because post-Causby landowners presumptively own the airspace above their land, the balancing test in Causby is best understood not as a test of the reaches of the landowner's ownership of the air, but as a test of when that property has been taken. For the government to "take" property, another must own the property. ${ }^{42}$ As this Article explains in Part IV, other cases show that formal forced easements are problematic because of their permanent and trespassory nature. So, Causby speaks to overhead flights that are not from formal easements but are so frequent and intrusive they become like easements, and thus are takings.

\section{The Navigability Exception to Exclusionary Rights}

Landowners' exclusionary rights sometimes must yield to the common law doctrine of navigability. ${ }^{43}$ Some resources, especially water, must be kept open to travel even if the landowner may take advantage of other sticks in the bundle of rights over that space, like the right to sell. ${ }^{44}$ Even so, because of landowner expectation interests and the alternative means of travel available, the rules of navigable waters should not apply to low-altitude airspace.

The doctrine of navigability states that private parties who own property with surface water must sometimes allow others to pass through on that water. ${ }^{45}$ This doctrine developed mostly in the 19th

39. Id. at 183 .

40. $I d$.

41. See, e.g., Easement, Black's Law Dictionary (10th ed. 2014).

42. U.S. Const. amend. V. (The Takings Clause prohibits "private property" from being taken for public use without just compensation. The Clause is therefore only applicable in instances where the taken property belonged to a private entity at the outset.).

43. See, e.g., Maureen Brady, Defining "Navigability": Balancing State-Court Flexibility and Private Rights in Waterways, 36 CARDOzo L. Rev. 1415, 1419 (2015) (explaining that "[n]avigability comes into state law through operation of the public trust doctrine, which dictates that the public has property rights in some natural resources that can be asserted to prevent actions by individuals or the government that impinge on those rights").

44. $I d$.

45. Id. 
century when the logging industry started to boom. ${ }^{46}$ Courts began to hold that private landowners must allow logs to be shipped on the water passing through their land. ${ }^{47}$ Over the years, different states have classified waters as "navigable" based on different measures, such as whether a log could float on it, whether a vessel could sail on it, or whether it could be used recreationally. ${ }^{48}$ Owners of "navigable" waters lost their right to exclude parties who used the water for qualified purposes.

Courts placed these obligations on landowners partially because of industry necessity. The logging industry became important to 19th century society, and water-based shipping was the primary means of commercial transport long before that. With the railroad system relatively new to the scene as a feasible alternative for large-scale shipping, water was among the most effective channels for intra-national commercial travel. ${ }^{49}$ If loggers could not ship by water, they could hardly ship at all. ${ }^{50}$ On the backdrop of the deep-rooted importance of water transport to commerce, courts in the 1800s concluded that all private ownership carried an implied limitation on the right to exclude people from using waters suited for transport. ${ }^{51}$

Implied navigability probably should not apply to low-level airspace because such space is neither historically nor currently crucial to commerce and travel. By the time 19th century courts required landowners to keep waterways open, waterway shipping was long established. Low-altitude airspace, however, has not yet been substantially used for shipping or travel. Most shipping and travel within the United States occurs either on the ground or in high-altitude airspace..$^{52}$ So, today's shippers and travelers have different expectations than loggers did. In the 19th century, companies would have had to reorganize

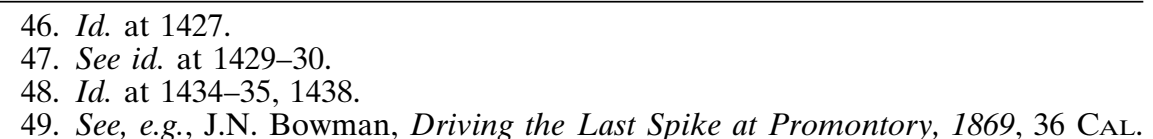
Hist. SoC'Y Q. 97 (1957) (explaining that the first transcontinental railroad was completed in 1869).

50. Brady, supra note 43, at 1429 ("Without giving the public uninhibited use of even trivially passable waterways, [courts] reasoned, wood could not make it to market.").

51. See, e.g., Morgan v. King, 35 N.Y. 454, 458 (N.Y. Ct. App. 1866) ("There can be no doubt that the rule of the common law, as to what degree of capacity renders a river navigable, in fact, should be received, in this country, with such modifications as will adapt it to the peculiar character of our streams, and the commerce for which they may be used.") (emphasis added).

52. See, e.g., Jerry Hirsch, 253 Million Cars and Trucks on U.S. Roads; Average Age is 11.4 Years, L.A. Times (June 9, 2014, 8:36 AM), http://www.latimes.com/business/autos/la-fi-hy-ihs-automotive-average-age-car-20140609-story.html (noting how the number of cars and trucks regularly traveling on roads in the U.S. reached a record high at the time of the article); National Oceanic and Atmospheric Administration, Air Traffic, NOAA, https://sos.noaa.gov/datasets/air-traffic/ (last visited Apr. 22, 2018) (noting that there are over 2,000 cargo airplane flights per day in the United States). 
their entire business model to operate if they could not access navigable waters. But today few to none would have to change current practices if they could not access low-altitude airspace; they do not use it in the first place.

They do not use low-altitude airspace because there is no practical necessity to use it like there was for water in the 1800s. Because ground and airplane transportation is expansive and sophisticated, probably no industry will collapse without the additional availability of low-altitude airspace transportation. True, future advances in drone technology may make low-altitude airspace shipping much more efficient and profitable compared to ground and airplane shipping. Courts may also feel more pressure to redefine navigability in the interest of economic efficiency. However, they should mind the constitutional limitations to making unforeseeable changes to established property rights. ${ }^{53}$

Landowner expectation interests also disfavor implied navigability in low-altitude airspace. A landowner with navigable water is on notice as to exactly what portion of the property will be stuck with an implied easement, not only because the common law says so, but also because the water itself occupies a determinate area. Imagine a developer who purchases a parcel of land in the suburbs. The land has a large stream running across the middle. Upon learning the water is navigable, the developer would know it could not alter the stream so as to make it untraversable from upstream. As the developer went about its business, making an apartment building, perhaps, it could build to its heart's content and on its own time, knowing that its rights as to the stream stay ever-constant.

Alternatively, imagine that instead of a stream, the land has air above it (as land tends to have). Upon learning that third parties hope to traverse that air, the developer would have a predicament. The air is not a narrowly defined corridor like the stream; it is allencompassing, at least up to 500 feet. If the developer thought navigability applied to low-level airspace, it would have two options: (1) do not build upwards at all for fear of encroaching on areas that must be kept open, or (2) build upward, but design the structures in such a way that there is some amount of airspace open for travel. ${ }^{54}$ If it

53. See Brady, supra note 43, at 1418 (arguing that the Takings Clause, the Due Process Clause, or both, should constrain courts' abilities to redefine navigability in when doing so would amount to unforeseen changes in the law and interfere with landowner expectations); Hinman v. Pacific Air Transport, 84 F.2d 755, 757 (9th Cir. 1936) (". . . but we find nothing therein to negative the ad coelum formula. Furthermore, if we should adopt this formula as being the law, there might be serious doubt as to whether a state statute could change it without running counter to the Fourteenth amendment to the Constitution of the United States.").

54. The severity of the impact on landowner interests would, of course, vary based on the nature of the drone easement. This example has little relevance to instances where the government action simply permits drones to fly in airspace that is not other- 
chose the latter, the developer would be unsure whether it left open enough space, and whether it did so in the right part of the air. ${ }^{55}$ In both cases the developer's business interests are more hampered than by navigable water. Total prohibitions on building and uncertainty as to legal consequences are both more severe to developers than keeping open a preset narrow strip.

Water provides for easy outlining of the boundaries of the landowner's rights, but air does not, so subjecting low-altitude airspace to navigability rules necessarily devolves into questions like "how much air must I leave open?"; "which sections of the air must it be?"; and others that would cause developers to be hesitant in land development.

Navigability exceptions to exclusionary rights are unique to water. In Edwards v. Sims, the Kentucky Court of Appeals reaffirmed the ad coelum rule for below-surface property. ${ }^{56}$ There, the defendant had opened up a cave to the public for profit. ${ }^{57}$ The entrance to the cave was on the defendant's property, but the plaintiff suspected that the cave went under his surface land. ${ }^{58}$ The court granted the plaintiff a survey of the property, stating that because of ad coelum the plaintiff would have the right to exclude the defendant from using any portion of the cave beneath the plaintiff's land, even if the plaintiff could not make use of the space himself. ${ }^{59}$ Despite the dissent's conviction that the defendant should be able to make use of space that only he had worked to utilize, the majority held fast to the rule that landowners own the skies above and the depths beneath, regardless of economic efficiency. ${ }^{60}$

Post-Causby, courts have only limited the exclusionary rights provided by ad coelum for navigable water and navigable high-altitude

wise obstructed (for then the landowner would not be prevented from developing whatsoever). It would carry more weight in instances where the drone easement mandates that a landowner leave sufficient space for drone travel, and more weight still in instances where the easement requires a landowner to keep the entire airspace at a certain altitude open.

55. This is especially true if, as discussed above, the meaning of navigable airspace could change depending on the type of aircraft. The developer's low-altitude airspace that may not be navigable for planes may be navigable for helicopters. And the airspace not navigable for helicopters may be navigable for drones. Even if the government puts the developer on notice that "all your airspace is navigable," the developer would be unsure what that means - unsure as to what it could build and unsure how much the property value may otherwise be suppressed by overhead flights of various kinds.

56. Edwards v. Sims, 24 S.W.2d 619, 621 (Ky. 1929).

57. Id. at 619 .

58. $I d$.

59. Id. at 621-22 (Logan, J., dissenting) ("[the majority] deprives Edwards of rights which are valuable, and perhaps destroys the value of his property, upon the motion of one who may have no interest in that which it takes away, and who could not subject it to his dominion or make any use of it. . ..").

60. Id. 
airspace. These two exceptions were both driven by important commercial or travel industries, a feature that low-altitude airspace does not share. ${ }^{61}$

In other contexts, the common law treats low-altitude airspace as the surface landowner's property. Property rights include the right to exclude. Courts have made categorical exceptions to the right to exclude from certain types of property only when important and established industry required it. There is no comparable industry that would similarly require low-altitude airspace. Therefore, under current common law, surface landowners may exercise complete dominion over this space.

\section{Forced Drone Easements as Governmental Takings}

If the government required surface landowners to keep their lowaltitude airspace open to commercial drone travel, it might trigger a Fifth Amendment taking and require just compensation. The Causby Court, although dealing with especially obnoxious and frequent lowaltitude airplane flights, ${ }^{62}$ expressed that a permanent easement of flight may be a permanent physical occupation, which the Loretto Court later classified as a per se taking. ${ }^{63}$ If the essence of such taking is the restriction of the landowner's ability to exclude from or use the airspace, then forced drone easements may be per se takings. If forced drone easements are not similar enough to permanent physical occupations to be per se takings, they may still be regulatory takings under the Penn Central test.

\section{A. Forced Drone Easements as Permanent Physical Occupations}

The Supreme Court in Causby established that government flights over private airspace are takings whenever they are low enough and frequent enough to have a direct and immediate effect on the use and enjoyment of the property. ${ }^{64}$ The Court further explained that any permanent right of public travel through a landowner's airspace is a governmental intrusion of a particularly serious character. ${ }^{65}$ The Court has paved the way for the proposition that any government action providing a permanent easement of flight in low-altitude airspace is a taking. In Loretto, the Court held that a law requiring landlords to maintain a narrow television cable on their buildings was a taking. ${ }^{66}$ The Court stated that a per se taking occurs whenever the government causes the permanent physical occupation of a landowner's prop-

61. If this state of affairs were to change, the outcome would not necessarily be different with respect to navigability. See, e.g., Brady, supra note 43.

62. United States v. Causby, 328 U.S. 256, 258 (1946).

63. Loretto v. Teleprompter Manhattan CATV Corp., 458 U.S. 419, 430 (1982).

64. Causby, 328 U.S. at 266.

65. Id. at 264-65.

66. Loretto, 458 U.S. at 421. 
erty. ${ }^{67}$ If drone easements fell into this category, affected surface landowners would be entitled to just compensation without delving into nuisance-like balancing tests.

Although the Causby Court dealt with loud and frequent overpasses by large government airplanes, the rules that drove the Court may disfavor government action that keeps a landowner from making full use of her low-altitude airspace. The Court first limited the ad coelum rule to the extent that the rule prevented air travel at any altitude above private land. ${ }^{68}$ Yet, in the next breath, the Court reserved some of ad coelum's power, stating that landowners "must have exclusive control" over low-altitude airspace above their land. ${ }^{69}$ It therefore thought that any permanent easement of flight is like a fee interest taken over that airspace and thus a taking requiring just compensation. $^{70}$

The Court delivered the "use and enjoyment" standard to explain when there can be a taking from repeated trespass, even when there is not a forced easement of flight per se. ${ }^{71}$ Because the Causby Court expressly said a permanent easement of flight would amount to a shift in fee interest over that airspace, it implicitly recognized that when there is no question the government has prohibited the property owner from exercising dominion over his or her air, there is a per se taking, not subject to the "use and enjoyment" test. ${ }^{72}$

That a permanent easement of flight may be a permanent physical occupation also conforms to a common-sense inquiry into what a landowner has lost. Once it is determined that a landowner owns a certain section of air, it is easier to see why government action forcing the landowner to keep that air open to others' travel is a taking of that property. Before the governmental action, the landowner has the right to do with the air as he or she wishes, including travel, recreation, and development. He or she also may exclude others from doing

67. $I d$.

68. Causby, 328 U.S. at 264 (reiterating that "the airspace is a public highway").

69. Id.

70. Id. at 261-62. Before Causby, the 9th Circuit in Hinman, 84 F.2d at 758, seemed to indicate that there could be no trespass liability in low-altitude airspace unless the landowner was making actual productive use of the air. Causby put to rest the notion that there may be no taking unless the landowner actually uses the airspace. 328 U.S. at 264. Regardless of whether Causby effectively overruled this part of Hinman, the Hinman court did not close off the possibility that even if a landowner could not prove trespass liability, neither would he have to keep the airspace open for the unwanted flights to continue.

71. Id. Because the Court readily recognized permanent easements were permanent physical occupations, $i d$., the fighting issue in Causby is most reasonably understood as the question of when a permanent easement exists.

72. Alternatively, but in the same vein, the forced easement could also be thought to satisfy the "use and enjoyment" test. Just as the altitude and frequency of flights can determine that the landowner's use and enjoyment is so-interfered with as to de facto "take" the property, so too an undeniable forced easement distinctly removes the property from the owner's use and enjoyment. 
the same. After the government forces an easement, the landowner's rights are reduced to that of any member of the general public-probably limited to certain specific forms of transportation. The landowner has at minimum lost her right to exclude and likely a substantial portion of her right to use as well. These are part of the core bundle of property rights. ${ }^{73}$ If they are eliminated with respect to certain property, so that the landowner's rights look no different than anyone else's, the property has been taken from one party for the sake of many. The landowner would no more "own" the airspace than would Amazon or anyone else who now may fly a drone through it under the same claim of navigable right.

Compare an easement of flight to an overhead highway. Imagine a landowner owned a large plot of land in the country. She was free to build on the land as she wished. She could plant trees, fly planes, or even build tall structures like factories or phone towers. Imagine then the government built a highway over her land at an altitude of 100 feet. The government made clear she could drive on that highway just like anyone else, but she could do nothing to impede the travel of others. It is certain that the landowner originally owned the space through which the road was built. Yet it would be meaningless to say the landowner still "owned" the space afterwards by virtue of some title document because she could not exercise any of the unique rights of property owners.

This is precisely what the Causby Court seemed to have in mind when it effectively held that permanent easements of flight constitute permanent physical occupations. That Court made an analogy to an elevated railway with no supports touching the landowner's surface land. ${ }^{74}$ It explained that whether the landowner actually tried to occupy or use the airspace, the forced railway would be a taking of property because it would "subtract from the owner's full enjoyment of the property and ... limit his exploitation of it." 75

Perhaps one could argue that an elevated railway or interstate highway would be much more damaging than a drone "corridor," but this would ignore the difference between liability and damages. As the Court said in Cress, "it is the character of the invasion, not the amount of damage resulting from it ... that determines the question whether it is a taking." 76 The point of interest is the moment the government exercises influence over property in a way that moves the property out

73. See, e.g., Craig Anthony (Tony) Arnold, The Reconstitution of Property: Property as a Web of Interests, Harv. EnvTL. L. Rev. 281, 285 (2002) ("The rights most commonly identified with the property bundle include the right to exclude others, the right to possess, the right to use, and the right to alienate (or transfer or dispose of.)").

74. Causby, 328 U.S. at 264-65.

75. Id. at 265 .

76. United States v. Cress, 243 U.S. 316, 328 (1917). 
of the complete dominion and control of the private party. ${ }^{77}$ That moment is when the government effectually says to the landowner: "you must keep this space open."78 Once that happens, the landowner's rights are removed until further notice. It is irrelevant to the takings issue whether the government later allows someone to build a highway through the space, allows Amazon to fly drones at its leisure, or allows the local military base to test-fire rifles through it. ${ }^{79}$

In other words, there is a taking once the government supplants a private party's dominion and control with its own. The government cannot retroactively make the action not-a-taking simply by using its newly acquired property in a way that does not bother the prior owner as much. If the state took my land and used it to test new weaponry on the local wildlife, I would be thoroughly displeased. If it took my land and built an orphanage on it, I would enjoy some solace despite my loss. Yet, in either case, I would have suffered a taking entitling me to just compensation.

Therefore, the government could not avoid takings liability if it turns out a drone corridor is less obnoxious than a plane corridor. In either scenario, the landowner is deprived of her right to exclude, use, and develop in that airspace.

Because a forced and permanent easement of flight is much like a permanent physical occupation, it follows that forcing surface landowners to keep open a corridor for commercial drone flights is likely a per se taking. In Loretto, the Supreme Court found a per se taking from a law requiring landlords to permit cable television companies to install cable television equipment on their buildings. ${ }^{80}$ Even though the intrusion was only thirty-six feet of half-inch-wide cable, the Court held that such a permanent occupation, however small, effectively destroys the landowner's rights to exclude, possess, use, and dispose of property. ${ }^{81}$ The Court also explained that any regulation authorizing a permanent physical intrusion is a restriction of "an usually serious character" and almost necessarily a taking requiring just compensation. ${ }^{82}$ There has been a taking, regardless of whether the intrusion is particularly harmful to the property or whether the government has a compelling interest in the regulation. ${ }^{83}$

To better understand Loretto it helps to describe what does not count as a permanent physical occupation or intrusion. In Escondido,

77. See, e.g., Causby, 328 U.S. at 262.

78. See generally id.

79. See Portsmouth Harbor Land \& Hotel v. United States, 250 U.S. 1, 1-2 (1919).

80. Loretto v. Teleprompter Manhattan CATV Corp., 458 U.S. 419, 421 (1982).

81. Id. at 435 (explaining that permanent physical occupations "do[ ] not simply take a single 'strand' from the 'bundle' of property rights: [they] chop[ ] through the bundle, taking a slice of every strand.").

82. Id. at 426 .

83. Id. 
the Court said a rent control ordinance was not a per se taking. ${ }^{84} \mathrm{Al}-$ though the ordinance permanently mandated the amount landlords could charge for rent, the landlords were still free to choose their tenants. ${ }^{85}$ They still had the authority to decide whether to let people on their property; they simply were subject to pricing regulations once they had made that decision. If the law mandated that people rent their property to certain other private parties, it may have been a different story. In that case, the right to exclude and potentially the right to use, has been taken from the private party and placed entirely with the government. ${ }^{86}$ This distinguishes Loretto-style takings from other property regulations.

A forced easement of flight looks more like Loretto than Escondido. The government would be telling landowners they have to open a section of their property for public passage, whereas before the government action, the landowner could use and exclude others from that space as they wished.

What if, instead, the easement simply required the landowner to allow drone flights through its airspace to the extent the drones could traverse it but did not require the landowner to keep any specific portion of that airspace open? The landowner could perhaps still prove a per se taking. The analogies to the overhead highway or the cable would look slightly different. This form of easement would be like if the government periodically reconstructed the overhead highway to snake around the landowner's desired building projects or if the landowner could always decide where on its property the cable wire should sit. On the one hand, the landowner here would have more freedom to make use of the property-different than when a portion of the property is unambiguously and permanently removed from the landowner's control. On the other hand, the landowner would still suffer the permanent presence of a right of passage on its property. It keeps the right to use the property to some extent, but it permanently loses the right to exclude. These two considerations thus point in opposite directions on the takings issue, but the Loretto Court cared about both. 87

\section{B. Forced Drone Easements as Penn Central Takings}

Even if a forced drone corridor is not a Loretto-style taking, it might be a regulatory taking. In Penn Central, the Court held that a regula-

84. Yee v. City of Escondido, 503 U.S. 519, 527 (1992).

85. Id. at $530-31$.

86. Id. at 527 ("[t]he government effects a physical taking only where it requires the landowner to submit to the physical occupation of his land") (emphasis in original).

87. Loretto, 458 U.S. at 435 ("[T]he owner has no right to possess the occupied space himself, and also has no power to exclude the occupier from possession and use of the space."). 
tion prohibiting Penn Central from building a skyscraper on top of Grand Central Station was not a taking. ${ }^{88}$ It listed three factors to determine whether a regulation is a taking: (1) the character of the government action; (2) the extent of diminution in value of the property; and (3) the extent the regulation interferes with the property owner's reasonable investment-backed expectations. ${ }^{89}$ When landowners must respect a drone flight easement in their low-altitude airspace, the character of the government action weighs heavily in favor of the landowners' rights. The extent of diminution in value depends on the geographic region of the property and the extent the easement suppresses development. And the extent of interference with reasonable investment-backed expectations could vary substantially based on the particular owner (creating potential serious inequalities in what classes of people will have to suffer such easements without just compensation). The "character" factor alone may do enough work in the Penn Central analysis to classify these forced easements as takings because of the intrusive nature of such government action.

\section{The Character of the Government Action and its Unique Importance}

\section{a. The Precedential Weight of the Character Factor}

The more a governmental action is like a localized physical intrusion instead of a generally applicable regulation on behavior, the more likely the action will be a taking. This process acts as a sort of spectrum. ${ }^{90}$ At a certain level of intrusiveness, the regulation is a permanent physical occupation, which is a per se taking under Loretto. ${ }^{91}$ Yet, even if the intrusion does not go that far, it may still weigh heavily towards classifying the regulation as a taking under the "character of the government action" factor of the Penn Central test. ${ }^{92}$ So, as a government action looks more like a permanent physical occupation and less like a traditional regulation of landowner conduct, it shifts in character from not-a-taking, to almost presumptively a Penn Central taking, to a Loretto per se taking. Because a forced easement of flight is permanent and authorizes physical occupation by parties other than

88. Penn Cent. Transp. Co. v. New York City, 438 U.S. 104, 122 (1978).

89. Id. at 124 .

90. See Loretto, 458 U.S. at 430 ("[m]ore recent cases confirm the distinction between a permanent physical occupation, a physical invasion short of an occupation, and a regulation that merely restricts the use of property").

91. Id. at 421.

92. Id. at 433 (explaining that although "[an] easement of passage, not being a permanent occupation of land, was not considered a taking per se, [] a physical invasion is a government intrusion of an unusually serious character.") (citing Kaiser Aetna v. United States, 444 U.S. 164, 180 (1979)). 
the landowner, this factor weighs substantially towards considering such easements regulatory takings. ${ }^{93}$

For flight easements, this factor alone may be enough to prove a regulatory taking. It is uncertain how courts might apply the diminution in value and interference with expectations factors of the Penn Central analysis. Regardless, other considerations counsel as to why the "character of the government action" factor should be sufficient to prove a taking. The case law shows that there is a strong presumption of a taking when the governmental action is an intrusion of an unusually serious character. ${ }^{94}$

Forced easements categorically tilt the scale towards finding a taking, irrespective of other factors. The government action is more likely a taking when it can be characterized as an invasion on specific properties instead of as a regulation that merely "adjust[s] the benefits and burdens of economic life to promote the common good." 95 The Court has distinguished between "permanent physical occupation[s], [] physical invasion[s] short of [] occupation[s], and [ ] regulation[s] that merely restrict the use of property." 96 In Loretto, the Court seems to have put frequent low-altitude flights, like those in Causby, in the first category as per se takings, irrespective of the Penn Central test. ${ }^{97}$ The remaining two categories-physical invasions that are not Loretto takings, and any other less intrusive regulatory actions-are both subject to the Penn Central test.

However, courts presume that physical invasions short of occupations are nearly takings. In Kaiser Aetna v. United States, the Supreme Court found that a navigation servitude requiring a landowner to give the public access to its pond was a taking. ${ }^{98}$ It explained the difference between forced easements and other regulations challenged as takings, and affirmed the particular seriousness of the former:

This is not a case in which the Government is exercising its regulatory power in a manner that will cause an insubstantial devaluation of petitioner's private property; rather, the imposition of the navigational servitude in this context will result in an actual physical invasion of the privately owned marina .... And even if the Government physically invades only an easement in property, it must nonetheless pay compensation. ${ }^{99}$

93. Again, the analysis differs significantly depending on whether the easement limits landowner development by mandating certain airspace remain open, or if it merely requires the landowner to allow drone passage through airspace which the landowner chooses not to occupy itself.

94. Loretto, 458 U.S. at 433.

95. Penn Cent. Transp. Co. v. City of New York, 438 U.S. 104, 124 (1978).

96. Loretto, 458 U.S. at 430.

97. Id. at 432 (discerning that, "[t]he cases state or imply that a physical invasion is subject to a balancing process, but they do not suggest that a permanent physical occupation would ever be exempt from the Takings Clause.").

98. Kaiser Aetna v. United States, 444 U.S. 164, 180 (1979).

99. Id. 
Thus, even if the Court does not always consider physical invasions to be Loretto-style permanent physical occupations, forced easements still are especially intrusive even within the regulatory takings context. ${ }^{100}$

Removing a landowner's right to freely use and exclude others from a portion of their property has the same effect on their property rights as building a road through a section of their property; it is a governmental intrusion of an unusually serious character. ${ }^{101}$ Even if it would not qualify as a permanent physical occupation under Loretto, a strong showing on this factor will likely do most of the necessary work towards showing a Penn Central taking, irrespective of the diminution and investment-backed expectation factors.

\section{b. The Policy Significance of the Character Factor}

Some readers may still be surprised at this Article's extensive reliance on the "character of the government action" factor given that its meaning has long been somewhat obscure. ${ }^{102}$ This factor should not be ignored, especially when the challenged government action is more trespassory in nature. It serves as an even-handed constraint on the government that the other factors cannot always provide. In cases of government activity similar to trespass, this factor may do the majority of the work in demonstrating a Penn Central taking.

That the "character of the government action" factor can nearly foreclose any pushback from the other Penn Central factors should not come as a surprise considering the different facets of a takings action. The Takings Clause prohibits the government from taking private property for public use without just compensation. ${ }^{103}$ The action can thus be conceptualized in three parts: whether private property has been taken, whether such action is done for the public use, and what compensation to the private party is "just."104 Every takings principle and test discussed so far in this article relates to the first facet-whether private property has been taken. The classic taking is when government confiscates title over property. ${ }^{105}$ Permanent physical occupations are per se takings because that governmental action is functionally similar to the taking of title over a section of property. These occupations are takings regardless of the amount of resulting

100. Loretto, 458 U.S. at 433.

101. See, e.g., supra section III.A.

102. See, e.g., John Echeverria, A Turning of the Tide: The Tahoe-Sierra Regulatory Takings Decision, 32 EnvtL. L. Rep. 11235, 11246-47 (2002) (describing the "character of the government action" factor as "amorphous" and "seemingly open-ended.").

103. U.S. Const. amend. V.

104. See id.

105. See, e.g., Loretto, 458 U.S. at 431 (noting that a taking "was as clear as if the Government held full title and ownership.") (citing U.S. v. Peewee Coal Co., 341 U.S. 114, $116(1951))$. 
pecuniary damage to the property owner. ${ }^{106}$ In the Penn Central analysis, the "extent of diminution in value" factor can speak to whether there is a taking because it can help point to whether the regulation "goes too far." 107 However, in cases of physical invasions like in Kaiser Aetna, it is clear that the governmental action goes too far without any need to consult the resulting damage. ${ }^{108}$ The character of the government action is so much like the taking of title that the Takings Clause is implicated almost by default.

As a policy matter, if the character of the government action could not carry so much weight, Takings Clause jurisprudence might systematically disfavor less wealthy property owners. Wealthier landowners can satisfy the "interference with reasonable investment-backed expectations" factor of the Penn Central test much easier than poorer landowners. The "character of the government action" factor draws a line at the boundaries of what counts as property. Since governments already are more likely to take property in poor areas because just compensation will be lower, ${ }^{109}$ courts should hesitate to give improper weight to factors in the Penn Central test that would exacerbate the inequality.

Eminent domain already has a problem with unequal effects. The clearest examples of this are the locations of interstate highways and large stadiums. ${ }^{110}$ It serves the government's purse to disproportionately place these in poorer areas. While we all know the shortest distance between two points is a straight line, it may not be the cheapest distance. It might cost the government one million dollars more in construction expenses to build a longer highway that avoids a wealthy area. Yet, the government will still do it if just compensation is over one million dollars less. In the same way, assuming the government

106. See generally id. at 438 (finding a forced television cable was a taking, regardless of the fact that the government action may actually increase the value of the property).

107. Pa. Coal Co. v. Mahon, 260 U.S. 393, 414-16. (1922).

108. See supra note 36 and accompanying text (explaining that, in trespass actions, liability is not dependent on a showing that the land was harmed).

109. See generally, Paul Boudreaux, Eminent Domain, Property Rights, and the Solution of Representation Reinforcement, 83 DENV. U. L. REV. 1 (2005) (addressing corrective mechanisms for governments' tendencies to use eminent domain in ways that disproportionately harm the poor).

110. See, e.g., Ashley Halsey, A Crusade to Defeat the Legacy of Highways Rammed Through Poor Neighborhoods, WAsh. Post (Mar. 29, 2016), https://www.washington post.com/local/trafficandcommuting/defeating-the-legacy-of-highways-rammedthrough-poor-neighborhoods/2016/03/28/ffcfb5ae-f2a1-11e5-a61f-e9c95c06edca_story. $\mathrm{html}$ ? noredirect=on\&utm_term=.978c349bd0d6 [https://perma.cc/S6H8-LPUP] (reporting evidence "that bulldozing highways through where poor people lived was public policy in the mid-20th century"); Dominique Wilkins, The Effect of Athletic Stadiums on Communities, with a Focus on Housing, 88 Int 'L Dev. Community \& ENV'T 1, 1 (2016) http://commons.clarku.edu/cgi/viewcontent.cgi?article=1016\&con text=idce_masters_papers [https://perma.cc/S6LA-5HRV] (observing that "[m]any new athletic stadiums have been constructed in low- and moderate-income areas with high minority populations ...."). 
seeks the most cost-effective method of reaching a goal, it will more likely place the new football stadium in a place where the just compensation due for taking ten acres of private land is half that of the cost of just compensation in a wealthier area.

This may not seem particularly unjust as an original matter: poorer residents may be disproportionately pushed out of their current homes, but they are paid accordingly. That is the point of "just compensation," right?

But there is another problem: that of the surrounding landowners whose property was not taken for just compensation but who still suffer harm to property values because a busy highway or noisy stadium parking lot is now 100 feet away. These people must initiate their own costly legal proceedings to combat this harm but likely would have no recourse, at least under the Takings Clause. ${ }^{111}$ So there are two likely results: (1) they keep their home as the surrounding area continues to deteriorate for lack of quality residential investment (a sort of positive feedback cycle) or (2) they could sell for a substantially lower price and be forced to relocate carrying less cash in hand than their home was once worth to purchase a lower-quality house in another area, where the government may again choose to build another road or stadium soon, starting the problem all over.

Therefore, courts should not further disadvantage less wealthy landowners by removing the protective force of the "character of the government action" factor compared to the "interference with reasonable investment-backed expectations" factor. Wealthier landowners may more readily prove interference with reasonable investment-backed expectations because they are more likely to have the funds to invest in property development and other capital-intensive land uses. Less wealthy landowners are rarely in a position to invest in significant development such that limits on their use of land would interfere with their immediate plans.

Perhaps one may counter that this also is a fair result. One could argue that while it hurts a landowner to impede development it had the money to execute, it does not hurt a landowner to tell them they cannot do something when they never had the funds to do that thing anyway.

This argument has more force in traditional regulatory takings contexts than for forced easements. Though some forms of land use regulations only become a burden to landowners who are practically able to engage in the now-prohibited action, forced easements burden landowners regardless of their future plans. If the local government

111. This is because, absent some sort of physical invasion, most regulatory takings claims fail. See, e.g., John Echeverria, Making Sense of Penn Central, 23 UCLA J. ENVTL. L. \& POL'Y 171, 183 (2005) (explaining that, in the regulatory takings context, "if property retains some economic value in the marketplace, a takings claim will likely fail, or at least the economic impact factor will not help the claimant."). 
orders that two properties, one owned by Ford Motor Company and one owned by a lower-income family, must not emit air pollutants past a certain low level, the takings analysis could come out differently. Ford would have a better shot at proving a taking since it has been substantially limited in what it can do with the automobile plant it just started building. This result seems just. The family would not have engaged in any activity creating such pollution anyway, so the ordinance would have no immediate practical effect. Consider, alternatively, a forced easement of flight. If Ford could prove they were counting on being able to obstruct the low-altitude airspace, or that drone flights would otherwise hamper its business practices, they would again have a better shot at succeeding on a takings claim. The end result for the other parcel, however, is not an unaffected family, but a family who cannot make a takings claim and is still stuck with a drone corridor over its house.

The "extent of diminution in value" factor of the Penn Central test helps to correct for some of this. But the point here is slightly different: In the above scenario, wealthier landowners have both the "interference" and the "diminution" factors at their disposal to limit such government actions or at least affect the government's cost considerations enough to incentivize the government to place the easements over poorer areas. Yet the less wealthy landowners have nothing but the "diminution" factor-probably not enough without the other factors to force the government to frequently pay just compensation and so be more hesitant to build undesirable projects in poorer areas.

The "character of the government action" factor comes to save the day, at least a little bit. This factor does not apply based on assessments of cost, but applies based on whether the government has done something similar to trespass. ${ }^{112}$ Trespass entitles the landowner to relief irrespective of the property damage caused by the trespass. ${ }^{113}$ It is thus a property, not a liability, rule. ${ }^{114}$ The introduction of this property rule into the takings analysis thus triggers the clause when a property right is infringed on at all, leaving the damage issue as a later question. This factor might not much affect the amount of compensation that is "just" once a taking is found. However, it does serve to increase the chance that a taking will be found in the first place, which

112. See, e.g., Kafka v. Mont. Dep't of Fish, Wildlife \& Parks, 201 P.3d 8, 28 (Mont. 2008) (explaining that the "character of the government action" factor involves an inquiry into "whether it is functionally comparable to government appropriation or invasion of private property.").

113. See, e.g., Jacque v. Steenberg Homes, 563 N.W.2d 154, 156 (Wis. 1997).

114. See Louis Kaplow \& Steven Shavell, Property Rules Versus Liability Rules: An Economic Analysis, 109 HARv. L. REv. 713, 715 (1996) (explaining that property rules "guarantee[] property right assignments against infringement through the threatened use of ... police powers," while liability rules "merely discourage[ ] violations by requiring transgressors to pay victims for harms suffered."). 
is important. Let's look again at the issue from the perspective of the government's purse:

Scenario 1: The government forces a drone easement into private airspace. Again, option 1 is to place the easement over the shortest distance between the desired points, but this track goes through some wealthier areas. Option 2 is to increase the distance of the drone easement to circumvent the wealthier areas and go through poorer areas instead. Assume, for the sake of argument, that in the wealthier area all of the landowners under the drone easement could have cognizable takings claims because they have the "interference" and "diminution" factors substantially working in their favor, but that in the less wealthy areas only about $10 \%$ of the landowners would have cognizable claims because the "interference" factor does nothing for them.

Scenario 2: All of the facts are the same as Scenario 1, except the "character of the government action" factor is also in play. Accordingly, a forced easement of any kind is highly suspect under the Takings Clause. Now, nearly every landowner in the less wealthy area has a cognizable takings claim (at least in the sense that the claims could run the gauntlet of litigation).

This shows that the "character of the government action" factor does legitimate work to increase the number of cognizable takings claims for less wealthy landowners. Now, it is true that a government choosing between paying just compensation for $\mathrm{X}$ distance of easement in a wealthier area and $X$ distance in a less wealthy area will still probably choose the less wealthy area. However, the calculus has changed where the government compares taking and paying for $\mathrm{X}$ distance in a wealthy area and $\mathrm{X}+Y$ distance in a less wealthy area. The character of the government action factor increases the number of properties in the less wealthy areas with cognizable takings claims. It will cost the government more to take a longer route even if the route goes through a less wealthy area-the government will be forced to pay out just compensation more often.

In some cases, this may persuade the government to run its drone easement through a short distance in a wealthy area instead of a longer distance in a poorer area. Given the present inequitable consequences of eminent domain use, the "character of the government action" factor may be one of the few supports for structural equality built into takings jurisprudence.

All this is not to propose sweeping reforms to eminent domain law or takings jurisprudence; it is simply to demonstrate that the "character of the government action" factor as it can be read now provides a valuable safeguard against inequalities that may not be addressable by other provisions (like the Equal Protection Clause). Policy considerations, therefore, support the precedent in justifying a special reliance on this Penn Central factor in the context of drone easements. 


\section{The Extent of Diminution in Value}

The value of airspace rights can vary based on geographic location, so it is difficult to say how much the "extent of diminution in value" factor of the Penn Central test weighs towards classifying forced drone easements as regulatory takings. The Penn Coal Court considered the extent of diminution in property value as a way to measure when a regulation has gone "too far." 115 There, the justices disagreed about whether the diminution in value should be measured against the property as a whole or against the particular right in question. ${ }^{116}$ This dispute has been called the "denominator problem."117 Later, in Penn Central, the Court resolved the dispute in favor of the "parcel as a whole" camp. ${ }^{118}$ A plaintiff property owner thus will not be able to prove its claim simply by showing that its rights as to one particular section of its property have been substantially eliminated. It must instead show that its loss substantially harms the value of the whole property. ${ }^{119}$

The value of the airspace above surface land may vary substantially by geographic area, making it difficult to assess the diminution in value in general, disconnected from any specific case. Different regions likely place different values on the ability to build upwards or even on the ability to develop at ground level free from aircraft flying closely overhead. In rural areas, property values may not be substantially enhanced by the landowner's ability to build vertically up to 400 feet. However, in many large cities where horizontal space is limited, the ability to build vertically without rising into an overhead drone swarm may make up a substantial portion of the property value. In New York City, for example, over 6,000 buildings exceed 100 feet in height. ${ }^{120}$ There, a forced drone corridor at a height of 100 feet, or even higher, could limit the number of potential tenants a developer may attain for their building spaces. The fair market value of a parcel burdened by a drone easement will be lower than a parcel without the easement.

Yet, even rural properties could suffer a diminution in value. This may come less from the limits on construction and more from intangi-

115. Pa. Coal Co. v. Mahon, 260 U.S. 393, 413, 415 (1922).

116. Id. at 419 (Brandeis, J., dissenting) ("If we are to consider the value of the coal kept in place by the restriction, we should compare it with the value of all other parts of the land. That is, with the value not of the coal alone, but with the value of the whole property.").

117. See, e.g., Giovanella v. Conservation Comm'n of Ashland, 857 N.E.2d 451, 456 (Mass. 2006).

118. Penn Central Transp. Co., 438 U.S. at 130-31 ("In deciding whether a particular governmental action has effected a taking, this Court focuses rather both on the character of the action and on the nature and extent of the interference with rights in the parcel as a whole ....").

119. Id.

120. Buildings in New York City (Existing), EMPORIs, https://www.emporis.com/ city/101028/new-york-city-ny-usa/status/existing/301 (last visited Sept. 14, 2019). 
ble drawbacks from aircrafts flying over private land at low altitudes. The market value of land could be affected by what happens directly above that land. Perhaps a potential buyer will be deterred from paying a certain price if they suspect they will often have to watch drones fly overhead. Not only may this impair serenity and aesthetics, but it may raise privacy concerns. Many private drones carry cameras, ${ }^{121}$ and a property's value may drop if members of the public can spy on the property from just above the surface.

The extent of diminution in property value could also vary based on the nature of the easement. There are two broad forms drone zoning could take: (1) a government mandate that landowners permit drones to fly through any airspace which the landowner does not occupy themselves with structures, or (2) a government mandate that certain airspace must remain unobstructed for drone travel.

In either case, the landowner will suffer a diminution in property value. In the first, from less tangible injury-losing the right to exclude and from having foreign objects swarm the air; in the second, from all of that plus restrictions on building. The diminution would be greater in the second.

\section{Interference with Reasonable Investment-Backed Expectations}

The more notice landowners have that they will be forced to allow a drone corridor over their land, the less likely the governmental action is a taking. The Penn Central Court listed "interference with investment-backed expectations" as a factor to consider in determining whether a regulation has gone too far and is a taking. ${ }^{122}$ The Supreme Court later clarified that only reasonable expectations of the property owner may factor into the analysis. ${ }^{123}$ Even so, a plaintiff can prove a taking when the regulation burdened the property at the time the plaintiff purchased it. ${ }^{124}$

As of now, the expectations of property owners may weigh towards classifying any forced easement of flight as a taking. First, there are no laws on the books right now forcing landowners anywhere in the United States to keep open a drone corridor above their land. Second, the common practice is to compensate landowners for flying above their land. In fact, post-Causby, it is the common practice of governments to compensate people near airports for easements of flight through their low-altitude airspace. ${ }^{125}$

Also, many developers would waste substantial funds buying property and planning for its development if, in the process, they learned

121. The Top Professional Drones for Serious Commercial UAV Pilots, UAV CoAcH, https://uavcoach.com/professional-drones/ (last visited Sept. 5, 2019).

122. Penn Central, 438 U.S. at 127.

123. See, e.g., Lucas v. S.C. Coastal Council, 505 U.S 1003, 1034 (1992).

124. Palazzolo v. Rhode Island, 533 U.S. 606, 628 (2001).

125. Rule, supra note 6, at 183. 
that their development was limited or burdened at the altitude of the mandatory drone corridor. For similar reasons as those discussed in the prior section on diminution in property value, investment money would be wasted and business growth would be frustrated.

\section{Takings Theory Applied to Forced Drone Easements}

Prominent theories predicting when courts will or should find a taking justify such a finding for forced drone easements. This Article will focus on two theories: Professor Michelman's felicific calculus ${ }^{126}$ and Professor Treanor's public choice theory of takings. ${ }^{127}$ Both of these tend to show that classifying forced drone easements as takings incentivizes the government to take only an economically efficient amount.

Under Professor Michelman's Felicific Calculus, a government should move forward with its action only when the benefits to winners exceed the costs to the losers. Winners' benefits are measured by the amount the private parties who want the government to act would pay to get the government to act. The loser's costs are measured by what those who do not want the government to act would accept in exchange for allowing the action. ${ }^{128}$ If the benefits exceed the cost and the government moves forward with its action, the government should compensate the losers whenever demoralization costs exceed settlement costs. ${ }^{129}$ Demoralization costs include detriment to all parties who see the government's action and are thereby discouraged to invest in their own property for fear of what the government may do in the future. ${ }^{130}$ Settlement costs are the dollar value of the time and resources those who want the government action would pay to privately settle with all those who would be negatively affected. ${ }^{131}$

Forcing drone easements may be inefficient in the first place. The benefits to the winners would be what the drone shippers like Amazon and similar entities, plus any lay persons particularly enthused about drone shipping, would pay to secure the drone easement. ${ }^{132}$ The costs to the losers would be the minimum amount that all negatively affected parties would accept to allow the drone easement. ${ }^{133}$

These specific amounts would vary based on locality, but this Article will focus on large cities like New York, because those are likely the first locations Amazon would install its "Hives."134 Again, air-

126. Frank I. Michelman, Property, Utility, and Fairness: Comments on the Ethical Foundations of "Just Compensation" Law, 80 Harv. L. Rev. 1165 (1967).

127. William Michael Treanor, The Original Understanding of the Takings Clause and the Political Process, 95 Colum. L. Rev. 782 (1995).

128. Michelman, supra note 126, at 1173-74.

129. Id. at 1214.

130. Id.

131. $I d$.

132. Id. at 1174 .

133. $I d$.

134. See Yurieff, supra note 2. 
space rights are probably more valuable in large cities. So the "losers" in the event of a forced drone easement would demand a substantial price to accept the easement. This price may exceed what Amazon and other drone shipping proponents would be willing to pay for a couple reasons. First, city road systems are so developed and dense that drones could fly entirely over public roads (avoiding private property law issues almost all together) without taking a particularly inefficient delivery route. Amazon may prefer to cut corners out of its flight paths. But if this only sheds a couple minutes off the delivery time, the benefit to Amazon would not likely exceed the cost to secure such easements in a place where air space is so valuable. Second, if ground shipping options are readily available, then customers may barely benefit from the additional use of drones.

If the government did choose to force drone easements, the felicific calculus would classify it as a taking and demand compensation. The calculus demands compensation when demoralization costs exceed settlement costs. ${ }^{135}$ Demoralization costs in this context would include all harm and anti-developmental incentives suffered by anyone who fears their property may become subject to a forced drone easement. Settlement costs would be the value of time and resources it would cost entities like Amazon to reach settlements with landowners they wish to subject to the easement.

The demoralization costs would likely exceed settlement costs here. If the government forced a drone corridor, developers city-wide might worry that any property they own or will soon acquire will be burdened by buzzing or limited in development options. More than likely, developers would be less willing to pay and invest in properties and may shift their focus to other regions where there is less of a risk of these forced easements. The settlement costs to Amazon would be more than pocket change, but probably less than the developers' collective fears. Amazon, without the government's help, would not have to acquire easements from thousands of landowners in the city. It would only have to acquire enough easements so that drone flight paths are efficient enough to justify the drone shipping practice overall.

Professor Treanor's public choice theory of takings takes a more political-democratic approach to identifying takings. The public choice theory seeks to protect property owners who suffer losses because of democratic "process failure." 136 Process failure occurs in one of two scenarios. The first is majoritarian process failure, where an individual landowner is powerless compared to the majority public. ${ }^{137}$ Professor Treanor focused on this form of process failure. Another form could be called minoritarian process failure, where the govern-

135. Michelman, supra note 126, at 1215.

136. Treanor, supra note 127 , at 784.

137. Id. at 855 . 
ment's action was brought about by biases created by the influence of special interests. ${ }^{138}$ In both these cases, declaring a taking and thus requiring the government to compensate forces democratic government to bear some of the pain of its occasional shortcomings. ${ }^{139}$

Imposing drone easements may amount to minoritarian process failure. If everyone who stood to materially benefit from forced drone zoning and everyone who stood to suffer some direct harm or threat to property rights from drone zoning were gathered for a vote, forced easements of flight would likely be voted down. ${ }^{140}$ However, that is probably not how the issue would be decided. Instead, the ones who want forced easements the most, Amazon and similarly situated parties, will likely push for the passage of drone zoning. ${ }^{141}$ Meanwhile, the at-risk land-owning population, though outnumbering the other side, will be scattered and less able to mobilize resources to tank the proposal. If the government approved it, it would contravene the majority will. Requiring the government to compensate all landowners burdened with the drone easements would either give the majority comfort in the face of the government's pursuit of minority interest or would be so expensive that the government would not exercise its eminent domain power against majority interests in the first place.

If, instead, the majority of people were in favor of forced drone easements, majoritarian process failure might result. Perhaps the majority of residents in major cities would like to have drones deliver packages to their balcony despite the political cost. A large portion of residents live in multi-unit apartment buildings or condominiums. ${ }^{142}$ But often only one person or entity on these lots actually owns development rights. So, even though the majority of landowners in the city may be against the measure, the large majority of voting residents are all for it. This is not an affront to democracy in itself, but it must be tempered by the Constitution, which secures protection against the

138. See, e.g., John McGinnis, Supermajority Rule as a Constitutional Solution, 40 WM. \& MARY L. Rev. 365, 372 (1999) (suggesting that "the fundamental pathology of modern spending patterns stems from the superior influence that concentrated interest groups wield with legislators, even though such groups are far less than a numerical majority").

139. Treanor, supra note 127 , at 858 . This is because, in either case, the government is constitutionally compelled to pay those who fall victim to the wills of the group that is able to persuade the government. $I d$.

140. Rule, supra note 6 , at 163 . As of now it is unclear drone shipping would substantially benefit anyone outside of companies like Amazon who are specifically lobbying for it. Conversely, it is clear that the practice may burden landowners. So, it is more likely at this stage that the immediate losers would outnumber the immediate gainers.

141. Supra note 4. Amazon Prime Air's proposal for drone zoning based on altitude level is an example. Id.

142. See, e.g., Quick Facts: Resident Demographics, Nat'l Multifamily Housing CouncIL, https://www.nmhc.org/research-insight/quick-facts-figures/quick-facts-resident-demographics/\#RentOwn [https://perma.cc/GMY7-W86H] (last updated Oct., 2018) (noting that 36 percent of households nationwide are renter-occupied.). 
"tyranny of the majority." 143 Take another constitutional provision for example: The fact that a majority of citizens may vote to censor a newspaper does not deprive the First Amendment of its power to prohibit government abridgement of speech. Likewise, a majority of citizens cannot vote-away the Takings Clause. If minority landowners cannot stop the drone corridor from moving forward in the political arena, the Takings Clause prevents majoritarian process failure by at least making the taxpayers pay for it.

The fate of forced drone easements is therefore the same under the Felicific Calculus and the Public Choice Theory: If the government wants to compel a transfer of property rights that private parties would not agree to on their own, it will have to pay for it. This deters the government from making decisions against the overall public interest, measured here by overall economic efficiency. Amazon and others will either have to incur settlement costs with other private landowners or put that cost on the government through a forced easement. If the latter, the Takings Clause insures that the cost does not fall solely on the landowners.

\section{Conclusion}

Amazon, Inc. has a plan to fill the skies with shipping drones. But to have a sufficient shipping system, Amazon would probably have to direct the drones over a lot of private land. Amazon maintains that the government could designate sections of low-altitude airspace as "zoned" for certain forms of drone flight. If the government chooses to force landowners to recognize a drone easement in their low-altitude airspace, whether or not the landowners have a takings claim depends first on whether they have a property interest in that airspace. The question of the upward reaches of a landowner's ownership has not been totally resolved, but there is sufficient precedent across the common law showing that landowners have exclusionary rights over low-altitude airspace.

Assuming this airspace does belong to the underlying landowner, the next question is whether the government "takes" that space by forcing the landowner to keep it open for drone flights. If a forced drone easement is like a permanent physical occupation then the action is a per se taking. Precedent supports this classification. Regardless, precedent and policy implications of the Penn Central test announce that forced easements of flight are governmental intrusions of a particularly serious character. That being the case, landowners have a good shot at making out a takings claim even if the drone corridor does not substantially impair their developmental expectations or property values. This is because the "character of the government ac-

143. See generally, The Federalist No. 10 (James Madison). 
tion" factor of the Penn Central test provides even-handed protection to all landowners subjected to trespass-like governmental action.

The Takings Clause provides necessary protections to landowners, ensuring that if the government takes from the one on behalf of the many, the funds of the many will compensate the one. Moving forward, Amazon will have a decision to make: buy easements from all property owners underneath its desired drone corridors, or lobby the government to declare a drone easement through eminent domain power. The latter course would not be easy, because the government may have to compensate every affected landowner. If not for Takings Clause protection, this issue would be decided purely by governmental volition: once the officials have enough desire to see delivery drones, they could make a sweeping mandate that all landowners must allow them to pass through unfettered. The general point of this Article, though, is that because of the substantial support the Takings Clause provides landowners, it is likely that whichever way drone shipping comes to fruition, the surface landowners will be compensated accordingly. 